\title{
Loans to Faculty Members in University Libraries
}

\begin{abstract}
A questionnaire was circulated to 120 university libraries requesting information as to loan policies to faculty members; 84 replied. Only three reported no limit on the loan period to faculty; 80 others reported loan periods ranging from two weeks to three years in length. Over half do not require that the volume be returned for renewal. Fining of faculty for overdues and losses has generally not been successful. Little consensus in practice appears from the survey.
\end{abstract}

O

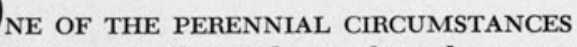
conditioning the relationship between academic librarians and faculty members is the loan of library materials. With certain exceptions, faculty members have traditionally been granted relatively free access to institutional library collections and indefinite loan privileges. No fines or fees have been assessed. But are these traditional concepts borne out in practice? The purpose of this paper is to describe the results of a questionnaire on the subject which was sent to university libraries in the United States and Canada.

A letter with a four-page questionnaire was addressed to 120 university librarians in December 1955 soliciting information on loan policies and practices for faculty members. This request was directed particularly to state universities, but some larger private institutions were included. Within two months eighty-four replies had been received, forming the basis for analysis.

The questionnaire called for detailed information on faculty loans of books, periodicals, and sets, including the number of volumes, government documents,

Mr. Haviland is Associate Librarian, University of Massachusetts. and microforms allowed to circulate at one time. Provisions for supplying desk, office, or laboratory copies required by faculty for indefinite periods and not subject to recall were also queried. Finally data was solicited on fines, processing fee, and replacement cost as well as provision for approval and enforcement of loan regulations. Study of these findings through the appended tables and consideration of the written discussion which follows will indicate how varied the loan practices are in university libraries.

Table 1 shows that almost all reporting libraries (eighty out of eighty-three) have loan policies involving a terminal date for the loan of a book to faculty members. Many of these responses describe the loan period as "indefinite."

Only three libraries, however, have faculty loan policies without due date or audit. Two of these libraries lend books to faculty for a calendar year or twelve months, while one has a three-year loan period. Seventy-nine university libraries out of the eighty-three responding have annual or shorter loan periods. Of these, forty-seven have an annual or academic year loan policy. Sixty-four libraries practice an annual audit of which fiftynine are library initiated and five are faculty initiated. Excluding the few ex- 
TABLE 1

Book Loan Periods to Faculty Members

\begin{tabular}{|c|c|c|c|c|c|c|c|c|c|c|}
\hline & & & & & & \multirow[t]{2}{*}{$\begin{array}{l}\text { NUMBER OF } \\
\text { LIBRAREES }\end{array}$} & \multicolumn{2}{|c|}{ AUdIT LIST FROM } & \multicolumn{2}{|c|}{$\begin{array}{l}\text { Book Returned For } \\
\text { PHYSICAL Check }\end{array}$} \\
\hline & & & & & & & Library & Faculty & No & Yes \\
\hline $\begin{array}{l}\text { No limit } \\
\text { Annual audit } \\
\text { Calendar-year loan } \\
\text { Three years } \\
\text { Six months } \\
\text { Due twice yearly }{ }^{\dagger} \\
\text { Three months } \\
\text { Semester, term, qua } \\
\text { Four weeks or mor } \\
\text { Three weeks } \\
\text { Two weeks } \\
\text { Totals }\end{array}$ & $\begin{array}{l}\text { iter } \\
\text { ith } \\
\text { ith } \\
\text {. }\end{array}$ & or & trimester & $\begin{array}{l}: \\
\vdots \\
\vdots \\
\vdots\end{array}$ & $\begin{array}{l}. \\
: \\
: \\
\therefore \\
. \\
.\end{array}$ & $\begin{array}{r}3 \\
45 \\
2 \\
1 \\
1 \\
3 \\
3 \\
13 \\
6 \\
1 \| \\
5 \\
83\end{array}$ & $\begin{array}{c}41 \\
2 \\
1 \\
1 \\
2 \\
2 \\
11 / 3 \ddagger \\
5 / 4 \ddagger \\
1 \ddagger \\
4 / 3 \neq 8 \\
70\end{array}$ & $\begin{array}{l}5 \\
5 \\
\vdots \\
\vdots \\
\vdots \\
\vdots \\
\vdots \\
\vdots \\
\vdots \\
\vdots\end{array}$ & $\begin{array}{r}3 \\
33 \\
-\quad 1 \\
1 \\
1 \\
1 \\
2 \\
4 \\
2 \\
1 \\
3 \\
51\end{array}$ & $\begin{array}{c}13 \# \\
2 \\
\vdots \\
2 \\
1 \ddagger \\
8 / 2 \ddagger \\
4 / 3^{\ddagger} \\
2 \\
32\end{array}$ \\
\hline
\end{tabular}

- Annual audit means renewal or return by end of academic year and includes as well those libraries reporting "indefinite" loan period ending in April, June, end of academic year, spring, summer or August.

† Books charged July/Dec. due in April on Jan./June due in Oct. One library sends typed charge card

to faculty when book falls due. He fills in call no., signs and returns to renew.

\& Quarterly audit.

\| Renewable for semester.

\# Includes one library which requires physical return of book after being on loan for 2 years, and one for 3 years.

$\ddagger$ Annually; $11 / 3^{\circ}$, for example, means that three of the total of 11 prepare a list annually, while the other 8 prepare a list each semester, etc.

ceptions noted above, university libraries lend books to faculty members for the duration of a specified period, be that the academic year or some other stated period.

The physical return of the book at a specified time for an audit is required by thirty-two libraries, 39 per cent of libraries responding, while forty-eight or 58 per cent of libraries replying, report that this practice is not required; three did not answer the question. Several respondents inserted comments as to the appropriateness or effectiveness of this practice. These comments tend to indicate that eight libraries which do not now require it would like to have the book physically returned, while nine which do request it meet with varying degrees of success. The figures in parenthesis by these comments indicate the number of responses:

- No, unfortunately, I wish they were (3)

-Not at present (1)

- No. We would like to have this done, but too many people object (the faculty, that is) (1)

- No, but I am trying to institute this (3)

-We encourage it (1)

-We request it, but do not enforce it (1)

-Faculty members are asked to return books once a year, but this has not been effective ( 1 )

TABLE 2

Faculty Charges for Losses and Overdues

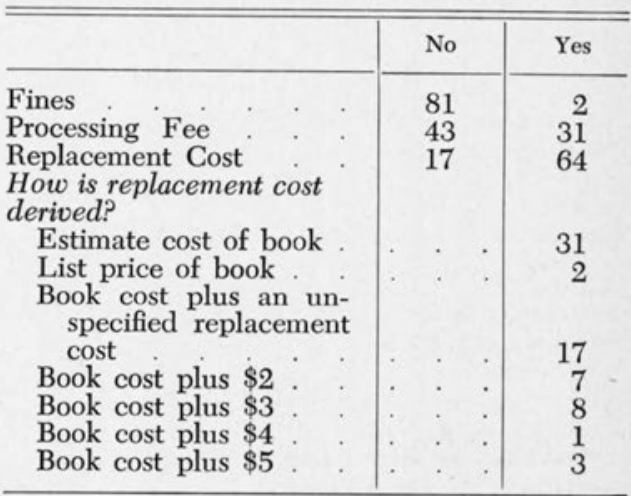


-Theoretically yes; actually no (1)

-Supposedly yes; if library list brings no response in a month, the book is automatically renewed ( 1 )

-Yes, but 100 per cent is not always achieved (3)

The responses seem to indicate that the trend is for an increasing number of university libraries to require the physical return of the book by faculty members and a diminishing number which do not.

In response to the question as to whether or not they fined delinquent faculty members, two institutions said yes, eighty no, and one did not answer. Thirty-one libraries, however, assess the faculty a processing fee for a lost book; forty-three do not. While replacement cost is reported as being assessed faculty by only sixty-four of eighty-one responding libraries, when answering specifically about how replacement costs are derived, fully sixty-nine institutions reported assessing some form of replacement cost. Table 2 analyzes these results in greater detail.
Conclusion. The best that may be said about the tabulated results of this survey of faculty loan regulations is that results are mixed. Almost every variety of regulation has its adherents. The traditionally

TABLE 3

Periodical Loan Periods to FACULTY MEMBERS

\begin{tabular}{|c|c|c|c|}
\hline & $\begin{array}{l}\text { Bound } \\
\text { Volumes }\end{array}$ & $\begin{array}{l}\text { Unbound } \\
\text { Volumes }\end{array}$ & $\begin{array}{l}\text { Latest } \\
\text { Issues }\end{array}$ \\
\hline $\begin{array}{l}\text { No limit } \\
\text { One year } \\
\text { Three months } \\
\text { Six weeks } \\
\text { Four weeks } \\
\text { Three weeks } \\
\text { Two weeks } \\
\text { Ten days } \\
\text { One week } \\
\text { Four days } \\
\text { Three days } \\
\text { Two days } \\
\text { One day } \\
\text { Overnight } \\
\text { Limited } \\
\text { Do not circulate } \\
\text { Renewal } \\
\text { Sets loaned }\end{array}$ & $\begin{array}{r}12 \\
2 \\
1 \\
1 \\
3 \\
1 \\
9 \\
1 \\
21 \\
9 \\
1 \\
4 \\
8 \\
7 \\
5 \\
46 \\
34 \\
\text { (in sets) }\end{array}$ & $\begin{array}{r}8 \\
1 \\
. \\
2 \\
1 \\
7 \\
1 \\
21 \\
1 \\
8 \\
2 \\
10 \\
5 \\
10 \\
. \\
.\end{array}$ & $\begin{array}{r}2 \\
24 \\
9 \\
33 \\
. \\
.\end{array}$ \\
\hline
\end{tabular}

- Indefinite - ordinarily loaned for academic year.

$\dagger$ Limited: for a short period of need.

TABLE 4

Document Loan Periods to Faculty Members

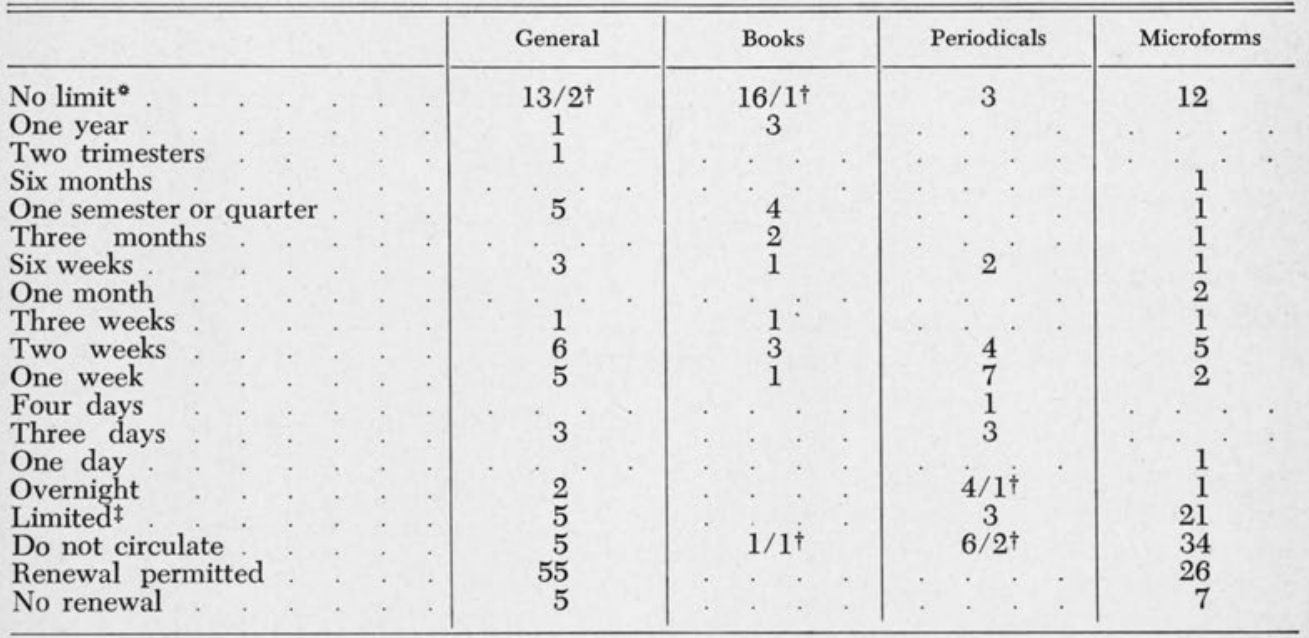

$\div$ With exceptions.

- Indefinite - ordinarily loaned for academic year.

$\ddagger$ Limited: for a short period of need. 
TABLE 5

Provisions for Supplying Desk Copies to Faculty Members

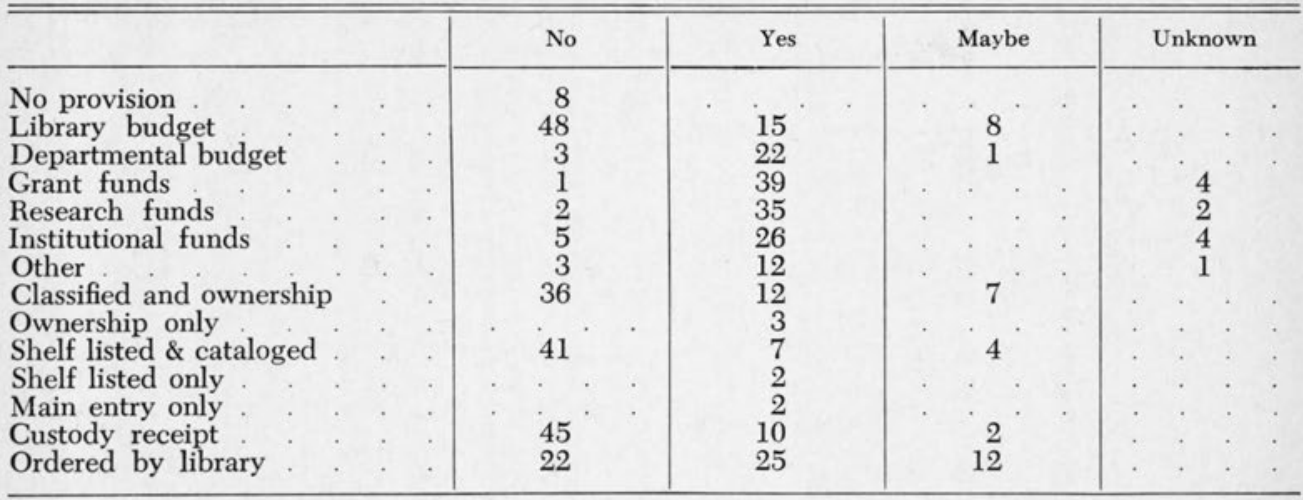

received concepts of indefinite loan but with some form of recurring accountability persist. In general, a small majority of the libraries expect faculty members to account for their borrowed material, while a few less than half of those responding expect books to be physically returned for renewal. Fully 65 per cent of the libraries replying prepare an annual audit list. Some 58 per cent indicate that the physical return of the book is not required, while 39 per cent do require its return for renewal. The comments accompanying this point indicate

TABLE 6

Purchase Approval for Faculty DESK COPIES

\begin{tabular}{lr}
\hline \hline Business office & 1 \\
Grantee & 10 \\
Dir. Gen. Research \& Comptroller & 1 \\
Dean, Librarian \& & 7 \\
Librarian & 8 \\
Acquisition Librarian & \\
Department Head & 79 \\
Unknown & \\
\hline
\end{tabular}

that a portion of those libraries which do not require a physical check wish that such a check were required. A portion of those libraries which do not require a physical check comment on the difficulty of locating titles when they eventually are recalled. Some libraries which do require the physical check comment that there is something less than complete compliance. The results of the survey indicate that there is no clear consensus among university librarians as to best practice.

TABLE 7

Arbiters of Faculty Delinguency

Board of Regents

Provost

V.P. for Academic Affairs

Pay withheld

Dean

Department Head

Librarian

Dir. of Public Services

Head of Circulation Department

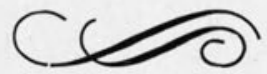

